\title{
Predictive capacity of prognostic scores for kidney injury, dialysis, and death in intensive care units*
}

\author{
Capacidade preditiva de escores prognósticos para lesão renal, \\ diálise e óbito em unidades de terapia intensiva \\ Capacidad predictiva de scores pronósticos para lesión renal, diálisis y óbito en UCIs
}

How to cite this article:

Vasconcelos GMT, Magro MCS, Fonseca CD, Oliveira JC, Santana-Santos E. Predictive capacity of prognostic scores for kidney injury, dialysis, and death in intensive care units. Rev Esc Enferm USP. 2021;55:e20210071. https://doi.org/10.1590/1980-220X-REEUSP-2021-0071

\section{Geferson Messias Teles Vasconcelos ${ }^{1}$ \\ Marcia Cristina da Silva Magro ${ }^{2}$ \\ Cassiane Dezoti da Fonseca ${ }^{1,3}$ \\ D Jussiely Cunha Oliveira ${ }^{1}$ \\ Eduesley Santana-Santos ${ }^{1}$}

* Extracted from the dissertation: "Incidência, fatores de risco e mortalidade em lesão renal aguda em unidade de terapia intensiva: coorte prospectiva",

Universidade Federal de Sergipe, Programa de Pós-Graduação em Enfermagem, 2021.

${ }^{1}$ Universidade Federal de Sergipe, Programa de Pós-Graduação em Enfermagem, Aracaju, SE, Brazil.

${ }^{2}$ Universidade de Brasília, Programa de Pós-Graduação em Enfermagem, Brasília, DF, Brazil.

${ }^{3}$ Universidade Federal de São Paulo, Escola Paulista de Enfermagem, Departamento de Enfermagem Clínica e Cirúrgica, SP, Brazil.
Corresponding author:

Geferson Messias Teles Vasconcelos

Av. Marechal Rondon, s/n, Jardim Rosa Elze

49100-000 - São Cristóvão, SE, Brazil

geferson_vasconcelos@hotmail.com

\section{ABSTRACT}

Objective: To assess the capacity of Charlson, SAPS 3 and SOFA scores to predict acute kidney injury, need for dialysis, and death in intensive care unit patients. Method: Prospective cohort, with 432 individuals admitted to four intensive care units. Clinical characteristics at admission, severity profile, and intensity of care were analyzed using association and correlation tests. The scores sensitivity and specificity were assessed using the ROC curve. Results: The results show that patients with acute kidney injury were older (65[27] years vs. 60[25] years, $\mathrm{p}=0.019)$ and mostly are from the emergency department $(57.9 \%$ vs. $38.0 \%, p<0.001)$, when compared to those in the group without acute kidney injury. For dialysis prediction, the results of SAPS 3 and SOFA were AUC: 0.590 ; 95\%CI: 0.507-0.674; p-value: 0.032 and AUC: 0.667 ; 95\%CI: 0.591-0.743; p-value: 0.000, respectively. All scores performed well for death. Conclusion: The prognostic scores showed good capacity to predict acute kidney injury, dialysis, and death. Charlson Comorbidity Index showed good predictive capacity for acute kidney injury and death; however, it did not perform well for the need for dialysis.

\section{DESCRIPTORS}

Acute Kidney Injury; Intensive Care Units; Dialysis; Death; Simplified Acute Physiology Score; Organ Dysfunction Scores. 


\section{INTRODUCTION}

Acute kidney injury (AKI) is a multifactorial clinical syndrome characterized by decreased glomerular filtration rate and/or urinary volume with consequent sudden renal impairment and damage to renal tissues ${ }^{(1)}$. Many patients admitted to intensive care units (ICU) are more susceptible to developing it, both due to their clinical instability and their greater exposure to risks because of hospitalization ${ }^{(2)}$. Thus, clinical practice has been based on identifying acute kidney injury using creatinine values during clinical care, as well as on determining the daily severity of patients and classifying the stage of kidney injury ${ }^{(1,3)}$.

To standardize the concept of AKI, and prevent and facilitate its diagnosis, the international guideline Kidney Disease: Improving Global Outcomes (KDIGO) was launched, with the perspective of guiding professionals in clinical practice and, consequently, reducing the high morbidity and mortality still found today ${ }^{(3-4)}$. Acute kidney injury staging, according to KDIGO, can be performed through the analysis of the increase in serum creatinine. It is stage 1 when creatinine is $\geq 0.3 \mathrm{mg} / \mathrm{dl}$ or $50 \%$ increase in baseline creatinine; lesion or stage 2 when the increase in baseline serum creatinine is $\geq 100 \%$; failure or stage 3 when the increase in baseline serum creatinine is $\geq 200 \%$ or renal replacement therapy is required. In addition, according to KDIGO, only patients classified as stage 3 are referred to renal replacement treatment $t^{(4)}$.

Nevertheless, patients who develop AKI have a propensity for negative outcomes, since renal function loss can lead to complications in other target organs, such as the brain, heart, and reduces the clearance of drugs, metabolites or other potential neurotoxins ${ }^{(5)}$. Furthermore, AKI accounts for the increased length of hospital and ICU stays, higher need for intensive and technological care. Therefore, the demand for a greater workload to the team and the greater need for clinical interventions are factors that directly influence the increase in hospital costs and morbidity and mortality ${ }^{(6)}$.

Different aspects influence incidence rates, which can still be affected by geographic aspects. While an international multicenter study showed a global AKI prevalence rate of $44.6 \%$ in patients in critical care units, specifically in South America a reduction was identified, $12.7 \%{ }^{(7)}$, but in another study this variation reached $20 \%$ to $40 \%$ of involvement ${ }^{(8)}$. However, despite advances in diagnosis and therapies, mortality has changed little in recent years, affecting $40 \%$ to $80 \%$ of patients admitted to ICUs, which emphasizes the need to implement tools to the earlier identification of acute kidney injury ${ }^{(9)}$.

One of the tools that can be adopted is the prognostic score to assist clinical practice and care management as a reliable predictor of hospital mortality in critically ill patients. The most used scores are the Charlson Comorbidity Index (CCI), which is a predictor of mortality according to patients' clinical conditions and morbidity; the Simplified Acute Physiology Score 3 (SAPS 3), the ICU scoring system also used to predict mortality risk; and the Sequential Organ Failure Assessment (SOFA), which uses clinical and laboratorial parameters to predict organ dysfunction, evaluating six systems (respiratory, hematologic, hepatic, cardiovascular, central nervous, and renal) $)^{(10-12)}$.

Despite being prognostic scores widely used in the ICU environment for various organ dysfunctions, there are gaps in the literature on their use as indices capable of predicting AKI, to contribute to the team's decision-making when evaluating the clinical conditions of patients and their prognosis ${ }^{(13)}$. Thus, the present study aimed to assess the capacity of the CCI, and of SAPS 3 and SOFA scores to predict acute kidney injury, need for dialysis, and death in intensive care unit patients.

\section{METHOD}

\section{Design of Study}

Prospective cohort study conducted between August 2018 and July 2019.

\section{SAMPLE}

This was a convenience sampling and consisted of patients admitted to four intensive care units during the period of data collection.

\section{LOCAL}

The study was carried out in four general ICUs located in the state of Sergipe: three from the public network and one from the private network. Among the public hospitals, two are large teaching hospitals linked to the Universidade Federal de Sergipe, one located in the capital and the other in the center-south region of the state; the third public hospital is a regional, medium-sized hospital, located in the Agreste area of the state; the private hospital is a general and large hospital, located in the capital of the state.

\section{Selection Criteria}

All patients admitted to the ICU with AKI defined by the use of the $\mathrm{KDIGO}^{(4)}$ classification criterion of creatinine level in any of the three stages, after admission to the ICU or upon prior medical diagnosis during the data collection period, were included in the study, provided that they were 18 years of age or older and with a minimum stay of 24 hours in the ICU. Patients with no serum creatinine results were excluded, which made it impossible to classify AKI between 48 hours and seven days. The imprecision in the recording of urinary volume due to the absence of an invasive urinary device in all patients prevented its use in the assessment of AKI according to $\mathrm{KDIGO}^{(4)}$.

\section{Data Collection}

A specific instrument for data collection was created, where information was registered in the following domains: demographic data; clinical features; support for admission to the ICU, and outcomes. Sample demographic and clinical characterization was carried out by analyzing the variables sex, age, weight, race, origin, comorbidities, use of 
medications, and predictive scores for mortality and organ dysfunction.

The prognostic prediction systems used were CCI, SAPS, and SOFA. It should be noted that these systems are validated for use in the clinical and hospital environments, with an emphasis on critically ill patients admitted to the ICU, being based on several subscores of organ failure. However, assessing these three scores regarding the prediction of AKI, dialysis, and death through the analysis of sensitivity and specificity is a challenge, given the scarcity of publications involving this association.

SOFA was used to identify organ dysfunction, describing the physiological disorders by organ system; SAPS 3 was used because it is a prognostic score for disease severity, with the purpose of predicting mortality based on data obtained on admission; and the CCI calculates the burden of morbidity and the patients' risk of death through the scoring of clinical conditions, recorded as secondary diagnosis ${ }^{(10-12)}$.

To identify the outcomes including acute kidney injury (AKI), hemodialysis (conventional hemodialysis), and death, daily records were performed, according to the collection instrument, for a period of seven days and/or until discharge from the ICU due to discharge, death, or transfer to another institution. To record the AKI outcome, creatinine was assessed according to the KDIGO classification between 48 hours and seven days to indicate the patient's injury stage. The laboratory tests (serum BUN and creatinine, electrolytes, liver profile) follow-up was performed using the medical records to assess the development of AKI and the outcomes recording.

Data were collected by a previously trained team with the participation of students from undergraduate (nursing, medicine, pharmacy, and physiotherapy) and graduate courses, and they were obtained from the daily consultation of the patient's medical record, with the help of the data collection instrument to systematize information obtainment.

To ensure that all the information needed for the study was collected, the researchers were divided into daily scales to carry out visits to the ICUs so that every day of the week at least two of these researchers were present in these units.

\section{Data Analysis and Treatment}

The data obtained were plotted in tables in the software Excel ${ }^{\circledR}$ 2019. Categorical variables were described using absolute and relative percentage frequencies. Continuous variables were described using median and interquartile range.

To allow the analysis of the data found, the sensitivity and specificity results were expressed as a Receiver Operating Characteristic (ROC) curve. This is a graphical method for evaluating, organizing, and selecting diagnostic and/or prediction systems. The method reveals the relationship between specificity and sensitivity through mapping continuous variables. Therefore, the larger the area under the curve, the greater the accuracy of the diagnosis ${ }^{(14)}$. ROC curves were constructed and Areas Below the Curve (AUC) were estimated for death, acute kidney injury, and dialysis related to Charlson, SAPS 3 and SOFA predictors. Two-way repeated measures analysis of variance (ANOVA) was performed where acute kidney injury was the independent variable and Fluid Balance, Creatinine, Diuresis, Hemoglobin, Lactate, Nursing Activities Score (NAS), Potassium, Sodium, SOFA, and BUN were the dependent variables over the 7 days. The significance level adopted was $5 \%$ and the software used was the R Core Team 2020.

\section{Ethical Aspects}

This study was approved by the Research Ethics Committee of the Universidade Federal de Sergipe in 2018, with a favorable opinion under number 2.830.187. Throughout the course of the investigation, patients' data confidentiality and anonymity were maintained and all the recommendations of the National Health Council Resolution No. 466/12 were followed.

Participants and/or their legal representatives signed the Free and Informed Consent Term after being informed about the objectives of the study, guarantee of data confidentiality and of their rights.

\section{RESULTS}

During data collection, 432 patients were evaluated for the study. The comparative analysis between the clinical and demographic characteristics of the individuals studied shows that the patients in the AKI group were older (65 [27] years vs. $60[25]$ years, $\mathrm{p}=0.019)$ and mostly from the emergency unit $(57.9 \%$ vs. $38.0 \%, p<0.001)$, when compared to those in the group without injury. Among the comorbidities, the presence of dyslipidemia (23.4\% vs. $13.9 \%, \mathrm{p}=0.020)$ and creatinine values above $1.5 \mathrm{mg} / \mathrm{dL}$ on admission $(41.8 \%$ vs. $10.5 \%, p<0.001)$ were more frequent in the group of patients with acute kidney injury (Table 1).

In the analysis of the admission profile, it is noted that patients in the group developing AKI used more norepinephrine $(35.1 \%$ vs. $15.9 \%, \mathrm{p}<0.001)$ and underwent more sedation with fentanyl citrate $(51.3 \%$ vs. $31.7 \%$, p < 0.001$)$ and midazolam hydrochloride ( $31.6 \%$ vs. $18.6 \%, p=0.003)$, as well as using more invasive devices such as a nasoenteric tube (NET) $(56.1 \%$ vs. $37.5 \%, \mathrm{p}=0.001)$, orotracheal tube (OTT) (52.6\% vs. 34.8\%, p = 0.001), and central venous catheter $(\mathrm{CVC})(50.9 \%$ vs. $39.0 \%, \mathrm{p}=0.028)$ when compared to those without AKI. Moreover, the admission severity measured by SAPS 3 (37.0 [19.0] vs. 25.0 [19.8], p < 0.001) and by Charlson score (4.0 [3.0] vs. 3.0 [4.0], $\mathrm{p}=0.004)$ was higher among patients with injuries than among those without injuries, respectively (Table 1).

Based on the stratification of patients with AKI in the three stages of the KDIGO classification, $37.4 \%$ were classified in stage $1 ; 19.1 \%$ in stage 2 ; and $43.5 \%$ in stage 3 . When the clinical outcomes of the patients included in this study were evaluated, a significant difference in relation to dialysis $(34.8 \%$ vs. $6.3 \%, \mathrm{p}<0.001)$ and mortality $(59,1 \%$ vs. $22.5 \%, \mathrm{p}<0.001)$ was observed.

Some variables showed an increase in the chance of developing AKI when evaluated individually. Among 
Table 1 - Clinical and demographic characterization of patients evaluated with and without acute kidney injury - Aracaju, SE, Brazil, 2019.

\begin{tabular}{|c|c|c|c|c|}
\hline Variables & $\begin{array}{c}\text { Total } \\
(\mathrm{n}=\mathbf{4 3 0})\end{array}$ & $\begin{array}{c}\text { AKI (+) } \\
(\mathrm{n}=115)\end{array}$ & $\begin{array}{c}\text { AKI (-) } \\
(n=315)\end{array}$ & $\mathrm{p}$-Value \\
\hline \multicolumn{5}{|l|}{ Sex, $n(\%)$} \\
\hline Male & $216(50.3)$ & $55(47.8)$ & $162(51.4)$ & \multirow{2}{*}{$0.508^{\circ}$} \\
\hline Female & $214(49.7)$ & $60(52.2)$ & $153(48.6)$ & \\
\hline Age in years, median (IQR) & $62(25)$ & $65(27)$ & $60(25)$ & $\mathbf{0 . 0 1 9}{ }^{w}$ \\
\hline Weight in $\mathrm{Kg}$, median (IQR) & $60.8(17.6)$ & $64.9(22.9)$ & $60.6(16.4)$ & $0.323^{w}$ \\
\hline \multicolumn{5}{|l|}{ Race, n (\%) } \\
\hline White & $188(59.3)$ & $57(62.6)$ & $130(57.8)$ & \multirow{3}{*}{$0.380^{\circ}$} \\
\hline Black & 125 (39.4) & $34(37.4)$ & $91(40.4)$ & \\
\hline Asian & $4(1.3)$ & $0(0)$ & $4(1.8)$ & \\
\hline \multicolumn{5}{|l|}{ Origin, n (\%) } \\
\hline Emergency & $185(43.2)$ & $66(57.9)$ & $119(38)$ & \multirow{4}{*}{0.001} \\
\hline Operating room & $154(36.0)$ & $14(12.3)$ & $139(44.4)$ & \\
\hline Internal Medicine & $74(17.3)$ & $30(26.3)$ & $44(14.1)$ & \\
\hline Surgical Clinic & $15(3.5)$ & $4(3.5)$ & $11(3.5)$ & \\
\hline \multicolumn{5}{|l|}{ Comorbidities } \\
\hline Heart Failure, n(\%) & $47(11.3)$ & $18(16.2)$ & $29(9.6)$ & $0.059^{\mathrm{Q}}$ \\
\hline Previous AMI, n(\%) & $45(10.7)$ & $9(8.1)$ & $36(11.7)$ & $0.301^{\mathrm{Q}}$ \\
\hline Systemic Arterial Hypertension, $\mathrm{n}(\%)$ & $212(50.0)$ & $63(56.3)$ & $149(47.9)$ & $0.130^{\mathrm{Q}}$ \\
\hline Dyslipidemia, n(\%) & $69(16.4)$ & $26(23.4)$ & $43(13.9)$ & $0.020^{\mathrm{Q}}$ \\
\hline Current Smoker, $\mathrm{n}(\%)$ & $43(10.2)$ & $10(9)$ & $33(10.6)$ & $0.625^{\mathrm{Q}}$ \\
\hline Previous Smoker, $\mathrm{n}(\%)$ & $110(26.0)$ & $28(25.2)$ & $81(26)$ & $0.865^{\mathrm{Q}}$ \\
\hline Basal Creatinine $>1.5 \mathrm{mg} / \mathrm{dL}, \mathrm{n}(\%)$ & $78(18.8)$ & $46(41.8)$ & $32(10.5)$ & $0.001^{\mathrm{Q}}$ \\
\hline Arrhythmia, $\mathrm{n}(\%)$ & $50(11.8)$ & $11(9.9)$ & $39(12.6)$ & $0.455^{\mathrm{Q}}$ \\
\hline Diabetes, n(\%) & $111(26.1)$ & $35(31)$ & $76(24.4)$ & $0.176^{\mathrm{Q}}$ \\
\hline Previous stroke, $\mathrm{n}(\%)$ & $56(13.2)$ & $17(15.3)$ & $39(12.5)$ & $0.459^{\mathrm{Q}}$ \\
\hline \multicolumn{5}{|l|}{ Admission support } \\
\hline Use of Dobutamine, $\mathrm{n}(\%)$ & $9(2.1)$ & $4(3.5)$ & $5(1.6)$ & $0.218^{Q}$ \\
\hline Use of norepinephrine, $\mathrm{n}(\%)$ & $90(20.9)$ & $40(35.1)$ & $50(15.9)$ & $0.001^{\mathrm{Q}}$ \\
\hline Use of Fentanyl, $n(\%)$ & 159 (36.9) & $59(51.3)$ & $100(31.7)$ & $0.001^{\mathrm{Q}}$ \\
\hline Use of Midazolam, $\mathrm{n}(\%)$ & $93(21.6)$ & $36(31.6)$ & $57(18.1)$ & $0.003^{\mathrm{Q}}$ \\
\hline Nasoenteric tube, $\mathrm{n}(\%)$ & $181(42.4)$ & $64(56.1)$ & $117(37.5)$ & $0.001^{\mathrm{Q}}$ \\
\hline Orotracheal Tube, n(\%) & 169 (39.5) & $60(52.6)$ & $109(34.8)$ & $0.001^{Q}$ \\
\hline Central Venous Catheter, $\mathrm{n}(\%)$ & $180(42.1)$ & $58(50.9)$ & $122(39.0)$ & $0.028^{\mathrm{Q}}$ \\
\hline Indwelling urinary catheter, $\mathrm{n}(\%)$ & $325(76.1)$ & $80(70.2)$ & $244(78.2)$ & $0.086^{\mathrm{Q}}$ \\
\hline \multicolumn{5}{|l|}{ Severity prediction scores } \\
\hline Admission SAPS 3, median (IQR) & $26(20.3)$ & $37(19.0)$ & $25(19.8)$ & $\mathbf{0 . 0 0 1}^{\mathrm{w}}$ \\
\hline Charlson score, median (IQR) & $3(4)$ & $4(3.0)$ & $3(4.0)$ & $0.004^{w}$ \\
\hline
\end{tabular}

$\mathrm{n}$ - absolute frequency. \% - percentage relative frequency; Pearson's Chi-Square Test. IQR - interquartile range; AMI - acute myocardial infarction; SAPS Simplified Acute Physiology Score; Q - Pearson's Chi-Square Test; W - Mann-Whitney test.

these, baseline creatinine $>1.5 \mathrm{mg} / \mathrm{dl}$ increased the odds by 6.27 times; the use of norepinephrine increased the odds almost threefold $(\mathrm{OR}=2.92)$; the use of mechanical ventilation $>48$ hours was related to a threefold increase of odds (OR: 3.05); the development of infection (OR: 2.09) and age (OR: 1.01) doubled the odds; and patients who developed pressure injury (PI) were 5.44 more likely to have the disease. In addition, when evaluated together - baseline creatinine $>1.5 \mathrm{mg} / \mathrm{dl}(\mathrm{ORa}=3.57)$, PI $(\mathrm{ORa}=3.12)$,
SOFA $(\mathrm{ORa}=1.30)$, and SAPS $3(\mathrm{ORa}=1,05)-$ greater odds of developing AKI was observed.

By evaluating the sensitivity and specificity for AKI of the CCI, SAPS 3 on admission, and SOFA of the first 24 hours of admission to the ICU, AUC of 0.591, p = 0.006; AUC $0.660, \mathrm{p}<0.001$ and 0.667 ; and AUC of 0.667, p < 0.001, were respectively observed (Table 2 and Figure 1A).

Regarding the capacity of these scores to predict the need for dialysis, only the Charlson Score showed no statistical 
Table 2 - Sensitivity and specificity of Charlson, SAPS 3, and SOFA scores for Acute Kidney Injury, Dialysis, and Death - Aracaju, SE, Brazil, 2019.

\begin{tabular}{lcccc}
\hline Variables & Area & SE & p-value & $95 \% \mathrm{Cl}$ \\
\hline $\begin{array}{l}\text { Acute kidney } \\
\text { injury }\end{array}$ & & & & \\
CCI & 0.591 & 0.032 & 0.006 & $0.528-0.653$ \\
Admission SAPS 3 & 0.660 & 0.030 & $<0.001$ & $0.601-0.720$ \\
SOFA & 0.667 & 0.030 & $<0.001$ & $0.609-0.726$ \\
\hline Dialysis & & & & \\
CCI & 0.565 & 0.044 & 0.124 & $0.478-0.652$ \\
Admission SAPS 3 & 0.590 & 0.043 & 0.033 & $0.507-0.674$ \\
SOFA & 0.667 & 0.039 & 0.000 & $0.591-0.743$ \\
\hline Death & & & & \\
CCI & 0.695 & 0.028 & $<0.001$ & $0.640-0.751$ \\
Admission SAPS 3 & 0.708 & 0.028 & $<0.001$ & $0.654-0.762$ \\
SOFA & 0.700 & 0.028 & $<0.001$ & $0.646-0.755$ \\
\hline
\end{tabular}

SE - Standard error. $95 \% \mathrm{Cl}$ - 95\% Confidence Interval; SAPS Simplified Acute Physiology Score; SOFA - Sequential Organ Failure Assessment; $\mathrm{CCl}$ - Charlson comorbidity index. significance (AUC: 0.565; 95\%CI: 0.478-0.652; p: 0.124). However, both SAPS 3 and SOFA for the first 24 hours of admission had an AUC of 0.590, p = 0.043 and AUC of $0.667, \mathrm{p}=0.039$, respectively (Table 2 and Figure $1 \mathrm{~B})$. In predictive capacity for death, CCI had an AUC of 0.695, $\mathrm{p}<0.001$; SAPS 3, AUC 0.708, $<$ < 0.001; and SOFA, AUC $0.700, \mathrm{p}<0.001$ (Table 2 and Figure 1C).

ANOVA results with repeated measures shown in Table 3 reveal the effects of AKI over the days on the variables described in the table; it is observed, therefore, that both AKI and the passing of days may change some of these variables; however, when the set day/time and AKI are evaluated, there is no change in any of them, that is, the effects are just individual. Therefore, when separately analyzed, it is noted that both AKI and the patient's stay in the ICU lead to changes in the SOFA score $(F=12.276 ; p<0.001$ and $F=3.299$; $\mathrm{p}=0.018$, respectively). However, the patient's stay in hospital only changes sodium levels $(F=5.940 ; p=0.005)$.

\section{DISCUSSION}

In this study, the capacity of prognostic scores to predict acute kidney injury, need for dialysis, and death in intensive
A



B

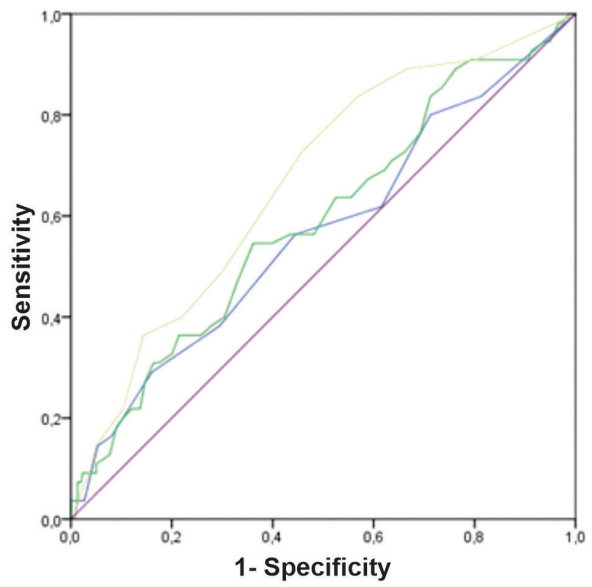

C



Origin of the curve

- Charlson score

SOFA_D2

- Reference line

Figure 1 - Predictability for the development of AKI, need for dialysis, and death through the application of Charlson, SAPS 3, and SOFA. (A) Predictive capacity of Charlson, SAPS 3, and SOFA scores for AKI; (B) Predictive capacity of Charlson, SAPS 3, and SOFA scores for dialysis; (C) Predictive capacity of ICC, SAPS 3 and SOFA for death. 
Table 3 - AKI effects during the days of hospitalization - Aracaju, SE, Brazil, 2019.

\begin{tabular}{lccc}
\hline Variables & $\begin{array}{c}\text { AKI } \\
\text { F (p-value) }\end{array}$ & $\begin{array}{c}\text { Day } \\
\mathbf{F} \text { (p-value) }\end{array}$ & $\begin{array}{c}\text { AKI vs Day } \\
\mathbf{F}(\mathbf{p} \text {-value) }\end{array}$ \\
\hline Fluid balance & $0.785(0.379)$ & $0.751(0.396)$ & $0.855(0.364)$ \\
Creatinine & $1.325(0.261)$ & $0.604(0.572)$ & $0.447(0.668)$ \\
Diuresis & $0.211(0.648)$ & $1.055(0.338)$ & $1.241(0.288)$ \\
Hemoglobin & $0.840(0.367)$ & $0.450(0.524)$ & $0.306(0.603)$ \\
Lactate & $0.036(0.857)$ & $0.237(0.961)$ & $1.505(0.205)$ \\
NAS & $1.107(0.294)$ & $0.429(0.720)$ & $0.964(0.405)$ \\
Potassium & $0.009(0.962)$ & $0.351(0.619)$ & $0.396(0.592)$ \\
Sodium & $0.009(0.925)$ & $\mathbf{5 . 9 4 0 ( 0 . 0 0 5 )}$ & $0.723(0.481)$ \\
SOFA & $\mathbf{1 2 . 2 7 6 ( < \mathbf { 0 . 0 0 1 } )}$ & $\mathbf{3 . 2 9 9 ( \mathbf { 0 . 0 1 8 } )}$ & $0.753(0.527)$ \\
Urea & $0.194(0.664)$ & $2.357(0.104)$ & $0.452(0.646)$ \\
\hline
\end{tabular}

F - F-Test Statistics; SOFA - Sequential Organ Failure Assessment; NAS - Nursing Activities Score; AKI - Acute Kidney Injury.

care unit patients in an emerging country was assessed. There were variations in the AUC of the three prognostic systems, with a minimum value of 0.565 to a maximum of 0.708. Therefore, this finding shows that, depending on the variable studied, these systems show predictive capacity for ICU patients. In addition, the results presented here allowed the identification of the incidence and of factors associated with AKI in the ICU.

Evaluating these three scores for the prediction of AKI, dialysis, and death through sensitivity and specificity analysis represents a challenge and makes this study unique, considering the scarcity of studies relating these three scores to the studied variables.

When evaluating the sensitivity and specificity for AKI of the scores studied, it was observed that all three scores had low predictive discrimination. However, although CCI is presented as a good prediction tool for other problems ${ }^{(15-16)}$, in this study a worse performance was observed when it was compared to the other two, thus not being a good prediction tool for this variable. The SOFA score was considered superior when compared to other scores to describe complications in critically ill patients with AKI in ICU ${ }^{(12)}$. The present study revealed similar predictive results for AKI with SOFA and SAPS 3.

Furthermore, when the capacity of these scores to predict the need for dialysis was assessed, the result was similar to that found with the AKI. However, only CCI did not show statistical significance. Nevertheless, both SAPS 3 and SOFA for the first 24 hours of admission showed low predictive discrimination. However, SOFA, among the three, was the one presenting the best AUC result, approaching the acceptable predictive value, a result that is close to what was found in the literature on predictive power of this score ${ }^{(17)}$.

Older age has been described in several studies as a risk factor for AKI, either in patients undergoing cardiac surgery, other surgical procedures, or in those admitted to ICU ${ }^{(18)}$. The increased probability of AKI in this population can be explained by several factors, such as comorbidities that give greater susceptibility to the development of AKI, use of polypharmacy, and possibly nephrotoxic invasive procedures, as well as physiological changes in the renal system involved in the senescence process. The presence of dyslipidemia and creatinine values above $1.5 \mathrm{mg} / \mathrm{dL}$ on admission were significant findings in the patients studied, with a predominance of those in the AKI group. These findings associated with comorbidities such as systemic hypertension and diabetes end up contributing to unfavorable outcomes for these patients $^{(19)}$.

In this study, a significant difference was observed between patients with and without AKI admitted to the ICU via the emergency unit. The possible explanation for this is these patients' severity, often progressing to hemodynamic instability. When the admission severity measured by the SAPS 3 and the CCI was assessed, an increase was observed among patients with injuries compared to those without injuries. Furthermore, the use of nephrotoxic drugs, hemodynamic changes, associated with hypovolemia, also significantly affected AKI in this investigation.

It is known that the use of vasopressor drugs contributes to nephrotoxicity, increasing the risk of AKI in critically ill patients ${ }^{(18)}$. Therefore, these results were similar to those found in this study, in which a greater need for these drugs and sedative drugs in patients in the AKI group was observed. Norepinephrine is a vasoactive drug (VAD) commonly used in the ICU, being a vasopressor of choice for hypotensive patients, provided that they are not hypovolemic. However, the use of this drug led to almost a three-fold increase of the odds of developing AKI in the patients in this study. Therefore, the use of VADs shall be carefully and consciously carried out, due to their hemodynamic instability, as well as their vasoconstrictor effect, which can indirectly lead to ischemia, with a consequent decrease in renal perfusion, especially in hypovolemic states ${ }^{(20)}$.

In the study, more than half of the patients in the AKI group needed to use mechanical ventilation (MV) for more than 48 hours, a finding that can be compared with the results of studies demonstrating that the use of these devices can lead to acute failure due to three main mechanisms, namely: effect on systemic and renal blood flow; effects on arterial gases and systemic release of inflammatory agents, generating immediate consequences on renal function, such as positive fluid balance; 20 to $40 \%$ decrease in urinary flow; sodium retention, causing a drop in cardiac output; and humoral changes, directly or indirectly affecting renal function $^{(2,21)}$.

As with the use of $\mathrm{MV}$, there was also a predominance of use of medical devices by patients with AKI, such as orotracheal tube, nasoenteric tube, and central venous catheter. More severely ill patients tend to need more devices, which favors the development of infectious processes. Therefore, the use of devices can be considered an indirect indicator of AKI. Additionally, in this study, almost half of the patients with AKI had an infectious condition. It is known that an antimicrobial therapy, used in most infectious conditions in the ICU environment, may be associated with AKI. In contrast, AKI can facilitate the development of infections, 
which makes it difficult to understand their cause and effect relation. However, a study proves that the association of sepsis with kidney injury leads to a worse prognosis in these patients ${ }^{(22)}$.

In this study, there was a significant incidence of PI development in AKI patients. This fact can be explained by several factors involved with AKI, such as the need for MV and vasoactive and sedative drugs, which make the patient's voluntary movement impossible, as well as prolonged hospital stay, which significantly affects PI development. Furthermore, it was observed that patients who developed PI are 5.44 more likely to develop AKI. This finding emphasizes the need for health teams, especially the nursing team, to be constantly vigilant, and that preventive measures are implemented, to prevent the development of this disease.

The length of hospital stay depends on several factors, ranging from the admission diagnosis and comorbidities to complications and injuries to which patients are subjected in the hospital environment. The literature cites an average length of stay of 8.6 days in the ICU ${ }^{(23)}$. Therefore, it is inferred that the median length of stay in the ICU of patients with AKI in this study was high (16.5 days), mainly due to clinical severity, which corroborates other studies. It should be noted that patients' extended stay in the ICU can negatively influence health status, with increased morbidity and mortality ${ }^{(2)}$. In addition, the association of AKI progression, increased clinical deterioration, and severity score is evidenced, conditions that are intrinsically related to worsening of prognosis and even death ${ }^{(24-26)}$.

When creatinine, PI, SOFA, and SAPS 3 are associated with each other, a greater chance of developing AKI was also observed. Therefore, these health care management tools can be excellent strategies to be used by professionals working in an intensive care environment to provide better outcomes for their patients.

Based on the data analyzed, almost half of those investigated with AKI progressed to stage 3 of KDIGO. However, $37.4 \%$ developed stage $1 \mathrm{AKI}$, which is similar to data from another study carried out with critically ill patients ${ }^{(25)}$. In addition, there was a significant number of patients requiring classic hemodialysis. Therefore, it is clear that even a small change in creatinine levels shall be carefully assessed and that KDIGO 1 is the ideal time for the initial assessment with the nephrologist. However, it is observed that this change is usually overlooked by professionals, with the assessment with a specialist usually coming late, when the patient is already at the most advanced levels of KDIGO, which is a major risk factor for worse outcomes ${ }^{(9)}$.

As in other studies, patients with AKI had higher mortality compared to those without AKI. Therefore, studies have shown that in developing countries AKI-associated mortality rate is higher, increasing by up to 4 times the risk of death in cases of AKI in ICU patients in emerging countries, mainly due to the limited resources available for its appropriate management ${ }^{(27-28)}$. This finding, therefore, reinforces the need to offer better quality care for this population, with strategies seeking the identification of groups with greater vulnerability, focused on the early detection and adoption of preventive measures against this problem ${ }^{(18,23)}$.

When evaluating predictability for death, the performance of the scores showed better results. However, although SOFA shows better results when compared to other $^{(14,17)}$ scores, the result in this study was very similar to that of the SAPS 3, but this does not overshadow its importance in predicting the prognosis of critically ill patients with AKI. The results found are close to the results found in other studies ${ }^{(14,29)}$, which allows concluding that these scores are useful to assess predictability of death in critically ill patients with AKI.

The practice of the multidisciplinary team should be based on avoiding adverse events and comorbidities that can be early identified, aiming at avoiding unfavorable outcomes and, therefore, improving these patients' prognosis. Thus, the role of nurses, together with the multidisciplinary team, shall be to provide the best care possible with the systematic use of the various technologies available, such as tools for predicting prognoses, to prevent the development of AKI, as well as the complications of hospitalization, or to minimize its effects, promoting better quality of care. Finally, a study has already found that there is a lack of knowledge among nurses about $\mathrm{AKI}^{(30)}$. This reinforces the professionals' need to seek scientific knowledge to meet the needs of patients under their care more effectively.

The results of the present study shall be interpreted in light of some potential limitations. First, the patients had different clinical pictures and levels of severity. Therefore, caution is required when making generalizations. It was developed in only one state; therefore, studies with a larger number of centers involved may provide more comprehensive data and promote more detailed comparative discussions on the subject studied. In addition, the percentage of patients who progressed with recovery of renal function was not evaluated. Finally, there is a risk of measurement bias, considering that data were collected from medical records, which may have wrong records.

It stands out for being a pioneering study involving these three prognostic scores with the variables AKI, dialysis, and death in patients admitted to the ICU, besides evaluating the incidence, risk factors, and mortality from acute kidney injury in different hospitals in an emerging country. Thus, this study creates possibilities for improving care and prediction for critically ill patients hospitalized in hospitals and similar environments.

\section{CONCLUSION}

This study showed that AKI in critically ill clinical patients is a multifactorial event, which occurs notably in older patients, with a predominance of males. In addition, it was observed that the predictive capacity of Charlson comorbidity index, SAPS 3, and SOFA for acute kidney injury and dialysis is limited; however, these instruments show good prediction when used for the variable death. Finally, this study opens perspectives for future research addressing this issue in different clinical contexts. 
RESUMO

Objetivo: Avaliar a capacidade dos escores Charlson, SAPS 3 e SOFA na predição da lesão renal aguda, necessidade de diálise e óbito em pacientes da unidade de terapia intensiva. Método: Coorte prospectiva, com 432 indivíduos internados em quatro unidades de terapia intensiva. Analisaram-se características clínicas na admissão, perfil de gravidade e intensidade dos cuidados por meio de testes de associação e correlação. A sensibilidade e especificidade dos escores foram avaliadas por meio da curva ROC. Resultados: Os resultados mostram que os pacientes com lesão renal aguda eram mais velhos (65[27] anos vs. 60[25] anos, $\mathrm{p}=0,019)$ e em sua maioria procedentes da unidade de emergência ( $57,9 \%$ vs. $38,0 \%, \mathrm{p}<0,001)$, quando comparados àqueles do grupo sem lesão renal aguda. Para a previsão de diálise, os resultados do SAPS 3 e do SOFA foram AUC: 0,590; IC95\%: 0,507-0,674; p-valor: 0,032 e AUC: 0,667; IC95\%: 0,591-0,743; p-valor: 0,000, respectivamente. Todos os escores apresentaram bom desempenho para o óbito. Conclusão: Os escores de prognósticos apresentaram boa capacidade para predizer lesão renal aguda, diálise e óbito. O Indice de Comorbidade de Charlson apresentou boa capacidade preditiva para a lesão renal aguda e óbito; entretanto, não apresentou bom desempenho para a necessidade de diálise.

\section{DESCRITORES}

Injúria Renal Aguda; Unidades de Terapia Intensiva; Diálise; Morte; Escala Psicológica Aguda Simplificada; Escores de Disfunção Orgânica.

\section{RESUMEN}

Objetivo: Evaluar la capacidad de los scores Charlson, SAPS-3 y (SOFA) en la predicción de la lesión renal aguda (LRA), necesidad de diálisis y óbito en pacientes de UCI. Método: Cohorte prospectivo, con 432 individuos ingresados en cuatro UCIs. Se analizó características clínicas en la admisión, perfil de gravedad e intensidad de los cuidados a través de testes de asociación y correlación. La sensibilidad y especificidad de los scores fueron evaluadas por medio de curva ROC. Resultados: Los resultados mostraron que los pacientes con lesión renal aguda eran mayores (65[27] años vs. 60[25] años, $p=0,019)$ y en su mayoría procedían de urgencias $(57,9 \%$ vs. $38,0 \%, p<0,001)$, cuando en comparación con aquellos del grupo sin LRA. Para la previsión de diálisis, los resultados del SAPS-3 y del (SOFA) fueron AUC: 0,590; IC 95\%: 0,507-0,674; p-valor: 0,032 y (AUC: 0,667; IC95\%: 0,591-0,743; p-valor: 0,000), respectivamente. Todos los scores presentaron buen desempeño para el óbito. Conclusión: Los scores de pronósticos presentaron buena capacidad en predecir LRA, diálisis y óbito. El Índice de Comorbidad de Charlson presentó buena capacidad predictiva para la LRA y óbito, sin embargo, no presentó buen desempeño para la necesidad de diálisis.

\section{DESCRIPTORES}

Lesión Renal Aguda; Unidades de Cuidados Intensivos; Diálisis; Muerte; Puntuación Fisiológica Simplificada Aguda; Puntuaciones en la Disfunción de Órganos.

\section{REFERENCES}

1. Doi K, Nishida O, Shigematsu T, Sadahiro T, Noritomo I, Iseki K, et al. The Japanese clinical practice guidelines for acute kidney injury. Clin Exp Nephrol. 2018;22:985-1045. DOI: https://doi.org/10.1007/s10157-018-1600-4.

2. Guedes JR, Da Silva ES, Carvalho ILN, De Oliveira MD. Incidência e fatores predisponentes de insuficiência renal aguda em unidade de terapia intensiva. Cogitare Enfermagem. 2017;22(2):e49035. DOI: https://doi.org/10.5380/ce.v22i2.49035.

3. Poston JT, Koyner JL. Sepsis associated acute kidney injury. BMJ. 2019;364:k4891. DOI: https://doi.org/10.1136/bmj.k4891.

4. Kidney Disease: Improving Global Outcomes (KDIGO). Clinical Practice Guideline for Acute Kidney Injury. Official Journal of the International Society of Nephrology [Internet]. 2012 [cited 2020 Sept 2];2(Suppl 1):1-138. Available from: https://kdigo.org/wp-content/ uploads/2016/10/KDIGO-2012-AKI-Guideline-English.pdf.

5. Siew ED, Fissell WH, Tripp CM, Blume JD, Wilson MD, Clark AJ, et al. Acute kidney injury as a risk factor for delirium and coma during critical illness. Am J Respir Crit Care Med. 2017;195(12):1597-1607. DOI: https://doi.org/10.1164/rccm.201603-0476OC.

6. Peres LAB, Wandeur V, Matsuo T. Predictors of acute kidney injury and mortality in an Intensive Care Unit. J Bras Nefrol. 2015;37(1): 38-46. DOI: https://doi.org/10.5935/0101-2800.20150007.

7. Hoste EAJ, Bagshaw SM, Bellomo R, Cely CM, Colman R, Cruz DN, et al. Epidemiology of acute kidney injury in critically ill patients: the multinational AKI-EPI study. Intensive Care Medicine. 2015;41(8):1411-23. DOI: https://doi.org/10.1007/s00134-015-3934-7.

8. Santos RP, Carvalho AR da S, Peres LAB, Delfino VDA, Grion CMC. Non-recovery of renal function is a strong independent risk factor associated with mortality in AKI patients. Brazilian J Nephrol. 2020;42(3):290-9. DOI: https://doi.org/10.1590/2175-8239-jbn-2019-0187.

9. Pinheiro KHE, Azêdo FA, Areco KCN, Laranja SMR. Risk factors and mortality in patients with sepsis, septic and non septic acute kidney injury in ICU. Brazilian J Nephrol. 2019;41(4):462-71. DOI: https://doi.org/10.1590/2175-8239-jbn-2018-0240.

10. Charlson, ME, Pompei P, Ales KL, Mackenzie CR. A new method of classifying prognostic comorbidity in longitudinal studies: development and validation. Journal of Chronic Diseases, 1987;40(5):373-83. DOI: https://doi.org/10.1016/0021-9681(87)90171-8.

11. Le Gall JR, Lemeshow S, Saulnier F. Simplified Acute Physiology Score (SAPS II) Based on a European/North American Multicenter Study. JAMA [Internet]. 1993 [cited 2021 Sept 2];270(24):2957-63. Available from: https://pubmed.ncbi.nlm.nih.gov/8254858/.

12. Carbonell N, Blasco M, Ferreres J, Blanquer J, García-Ramón R, Mesejo A, et al. Sepsis and SOFA score: related outcome for critically ill renal patients. Clin Nephrol. 2004;62:185-92. DOI: https://doi.org/10.5414/CNP62185.

13. Keegan MT, Soares M. What every intensivist should know about prognostic scoring systems and risk-adjusted mortality. Rev Bras Ter Intensiva. 2016;28(3):264-9. DOI: https://doi.org/10.5935/0103-507X.20160052.

14. Gong Y, Ding F, Zhang F, Gu Y. Investigate predictive capacity of in-hospital mortality of four severity score systems on critically ill patients with acute kidney injury. J Investig Med. 2019;67(8):1103-9. DOI: https://doi.org/10.1136/jim-2019-001003.

15. Bahlis LF, Diogo LP, Fuchsa SC. Charlson Comorbidity Index and other predictors of in-hospital mortality among adults with communityacquired pneumonia. J Bras Pneumol. 2021;47(1):e20200257. DOI: https://doi.org/10.36416/1806-3756/e20200257. 
16. Budweiser S, Harlacher M, Pfeifer M, Jörres RA. Co-morbidities and Hyperinflation Are Independent Risk Factors of All-cause Mortality in Very Severe COPD. COPD: Journal of Chronic Obstructive Pulmonary Disease. 2014;11(4):388-400. DOI: https://doi.org/10.3109/1 5412555.2013 .836174 .

17. Ferreira FL, Bota DP, Bross A, Mélot C, Vincent JL. Serial Evaluation of the SOFA Score to Predict Outcome in Critically III Patients. JAMA. 2001;286(14):1754. DOI: https://doi.org/10.1001/jama.286.14.1754.

18. Benichel CR, Meneguin S. Fatores de risco para lesão renal aguda em pacientes clínicos intensivos. Acta Paulista de Enfermagem. 2020;33:1-8. DOI: https://doi.org/10.37689/acta-ape/2020ao0064.

19. Schmidt L, Wiese LPL, Pereira EM, Possamai KS, Santos E, Fernandes FM, et al. Acute kidney injury in critical patients: profile clinical and relationship with serious processes infectious. Revista Brasileira de Farmacia Hospitalar e Serviços de Saúde [Internet]. 2020 [cited 2021 Sept 2];7(3):19-24. Available from: https://www.rbfhss.org.br/sbrafh/article/view/533.

20. Melo WF, Pereira AWR, Alves VQ, Saldanha HGAC, Sousa JS. Nursing care in emergency and emergency patient failure of victim Acute Renal: a literature review. Revista Brasileira de Educação Médica [Internet]. 2015 [cited 2021 Sept 2];5(2):6-11. Available from: https:// www.gvaa.com.br/revista/index.php/REBES/article/download/3647/3287.

21. Santos LL, Magro MCS. Ventilação mecânica e a lesão renal aguda em pacientes na unidade de terapia intensiva. Acta Paulista de Enfermagem. 2015;28(2):146-51. DOI: https://doi.org/10.1590/1982-0194201500025.

22. Faubel S, Edelstein CL. Mechanisms and mediators of lung injury after acute kidney injury. Nat Rev Nephrol. 2016;12(1):48-60. DOI: https://doi.org/10.1038/nrneph.2015.158.

23. Folkestad T, Brurberg KG, Nordhuus KM, Tveiten CK, Guttormsen AB, Os I, et al. Acute kidney injury in burn patients admitted to the intensive care unit: a systematic review and meta-analysis. Critical Care. 2020;24(1):2. DOI: https://doi.org/10.1186/s13054-019-2710-4.

24. Luft J, Boes AA, Lazzari DD, Nascimento ERP, Busana JDA, Canever BP, et al. Lesão renal aguda em unidade de tratamento intensivo: características clínicas e desfechos. Cogitare Enfermagem. 2016;21(2):1-9. DOI: https://doi.org/10.5380/ce.v21i2.43822.

25. Kane-Gill SL, Sileanu FE, Murugan R, Trietley GS, Handler SM, Kellum JA, et al. Risk Factors for Acute Kidney Injury in Older Adults With Critical Illness: A Retrospective Cohort Study. Am J Kidney Dis. 2015;65(6):860-9. DOI: https://dx.doi.org/10.1053/j.ajkd.2014.10.018.

26. Nascimento RAM, Assunção MSC, Silva Junior JM, Amendola CP, Carvalho TM, Lima EQ, et al. Nurses' knowledge to identify early acute kidney injury. Rev Esc Enferm USP. 2016;50(3):399-404. DOI: https://doi.org/10.1590/S0080-623420160000400004.

27. Bouchard J, Acharya A, Cerda J, Maccariello ER, Madarasu RC, Tolwani AJ, et al. Um estudo prospectivomulticêntrico internacional de AKI na unidade de terapia intensiva. Clin J Am Soc Nephrol. 2015;10(8):1324-31. DOI: https://doi.org/10.2215/CJN.04360514.

28. Santos RP dos, Carvalho ARS, Peres LAB, Ronco C, Macedo E. An epidemiologic overview of acute kidney injury in intensive care units. Rev Assoc Med Bras. 2019;65(8):1094-101. DOI: https://doi.org/10.1590/1806-9282.65.8.1094.

29. Maccariello ER, Valente C, Nogueira L, Ismael M, Valença RVR, Machado JES, et al. Desempenho de seis modelos de predição prognóstica em pacientes críticos que receberam suporte renal extracorpóreo. Revista Brasileira de Terapia Intensiva. 2008;20(2):115-23. DOI: https:// doi.org/10.1590/S0103-507X2008000200001.

30. Nascimento RAM, Assunção MSC, Silva Junior JM, Amendola CPa, Carvalho TM, Lima EQ, et al. Nurses' knowledge to identify early acute kidney injury. Rev Esc Enferm USP. 2016;50(3):399-404. DOI: https://doi.org/10.1590/S0080-623420160000400004. 